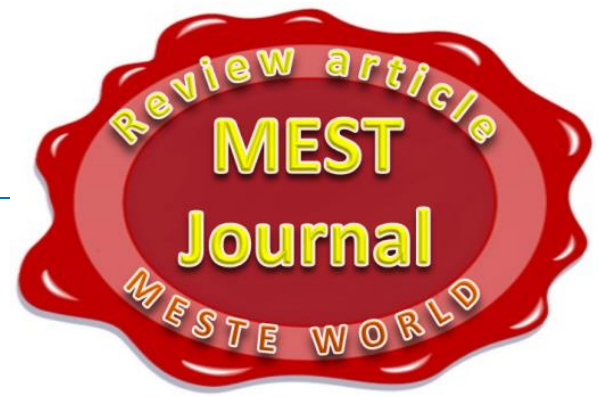

\title{
ECONOMIC SECURITY MANAGEMENT OF ENTERPRISES IN THE SPHERE OF CRIMINAL CHALLENGES
}

\section{Zinaida Zhyvko}

Management Department of Economics Faculty of Education and Research Institute of Law, Psychology and Economics of Lviv State University of Internal Affairs, Ukraine

\section{(C) MESTE NGO}

JEL category: M00, M1, M11, M15, M21

\begin{abstract}
:
The article analyzes and studies the basic aspects of economic security management of the enterprise, the place of information in the security of business activity of enterprises and investigates the possibility of criminal attacks on the country's economy through loss of information resources. After an analysis of some recent researches, and some aspects of economic security management, and enterprises as objects that provide strategic position to strengthen the economic security, author analyses information as the security object. At the end of the paper author concluded that the information management process of the enterprise includes: all the information necessary to manage all types of enterprise resources maintained in informational databases, development of informational environment for enhancing positive organizational activities of employees, providing them with the necessary information, and joining national or industrial search systems, receiving, storage, transmission and processing of information, i.e. the organization of appropriate databases.
\end{abstract}

Keywords: economic security, management, criminal challenges, European cohesion policy, presupposition, restrictions, information, management process.

\section{ANALYSIS OF RECENT RESEARCH}

Economic security management of enterprises in market conditions requires the development of methodological principles of management process using modern doctrines of knowledge

The address of the author:

Zinaida Zhyvko

莑”゙ zinaida_zhivko@mail.ru about security and their skillful application in the process of management. In addition to the general principles of business activity, it is necessary to have and effectively apply the basic methods of management of organization, personnel and security system at the enterprise. If managers have not got certain powers, responsibilities and knowledge, they (according to the domestic experience) convert to 
commercial agents, officials, administrators or functionaries.

Formation of the enterprises competitive position and insuring its strategic development in the context of enterprise security, various aspects of entrepreneurship are the subject of scientific interest of Ukrainian scientists.

However, speaking about the economic security management of enterprises in conditions of intense competition and development of criminal activity in economy there are still many unexplored aspects which will influence the financial and economic activity not only of a single enterprise but entrepreneurship in Ukraine as a whole.

\section{THE PURPOSE OF THE ARTICLE}

The purpose of the article is to learn about the basic aspects of economic security management of enterprises, to locate information in the business activity of enterprises and to explore the extent of criminal encroachments in the domestic economy.

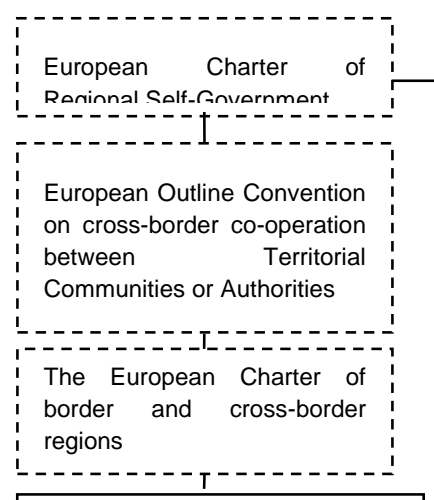

Regulation № 1082/2006 of the European Parliament and Council of 05.07.2006 was in respect of the European Association of territorial cooperation

European Commission Regulation № 1828/2006 of 12.08.2006 laying down general rules of Council Regulation № $1083 / 2006$ and Directive of the European Parliament and of the Council № 1080/2006



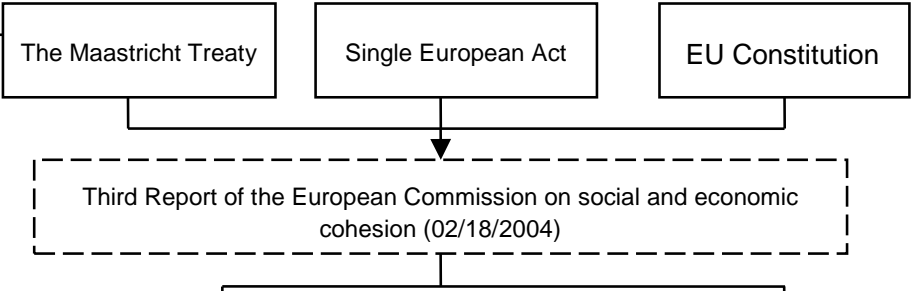

Regulation № 1081/2006 of the European Parliament and Council of 05.07.2006 was in respect of the European Social Fund (ESF)

Regulation № 1080/2006 of the European Parliament and Council of 05.07.2006 was in respect of the European Regional Development Fund (ERDF)

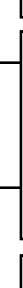

Regulation № 1083/2006 of the European Parliament and Council of 11.07.2006 laying down general rules for the ERDF, ESF and the Cohesion Fund

Council Regulation № 1084/2006 of 11.07.2006 was establishing a Cohesion Fund and cancel the order number 1164/94
Council Decision of 22.12.2004 was that modifies the decision 2000/24/WE, about EU enlargement and the European Neighborhoods Policy

Council Decision 2006/62/WE from 23.01.2006, the possibility of participation of countries covered by the European Neighborhoods Policy and Russia, the program of technical assistance and information exchange (TAIEX)

Directive of the European Parliament and of the Council № 1638/2006 of 24.10.2006 on general rules for the implementation of the European Neighborhoods and Partnership Instrument

\section{$+$}

2006/1016/WE Council Decision of 19.12.2006, the provision of guarantees Community European Investment Bank to cover expenses incurred in connection with loans and guarantees granted for projects outside the Community

Fig.1. Structure of the legal-regulatory provision of regional international cooperation within the European cohesion policy *Compiled according to (Sheil, 2008) (Czuzhikov, 2008) 


\section{PRESENTATION OF THE MAIN MATERIAL}

It is urgent for Ukraine to study the experience of European regional policy taking into consideration the proximity to the EU and the fact that the term of obtaining candidate status for accession to the Community remains uncertain, and implementation of European standards is very slow. Undoubtedly, improvement of the national institutional framework of regional development, i.e. regional entrepreneurship, introduction of systematic changes of institutional and structural character based on proven by EU tools and techniques of multilevel regional policy will improve the socio-economic development of local areas, will deepen the integration at the regional level and will develop the entrepreneurship and enterprise as its component.

\subsection{Strategic support of economic}

Strategic support of economic and institutional mechanism of enterprises economic security is executed for adaptation of the enterprise to the conditions of resource markets, for bringing into compliance the technical and technological basis of technological progress and for increasing the

\subsection{The structure of the legal-regulatory provision of regional international cooperation}

The structure of the legal-regulatory provision of regional international cooperation within the European cohesion policy in the sphere of legal and informational documents (Fig. 1).

Profitability of the enterprise. The main result of the strategic economic development is the formation of development strategy of economic and organizational mechanism for economic security.

Since the analysis of the enterprise activity is mainly based on the two-dimensional evaluation, which does not always reflect the real situation, let us consider a different approach, which we believe is more effective and adequate. In most cases, the great number of methods of strategic analysis is reduced to matrix methods (e.g. matrix of I. Ansof, M. Porter, Boston Consulting Group, McKincey, Arthur D. Little, etc.).
The basis of the strategic matrix is a combination of two criteria, in particular, the rate growth of industrial market and relative market share (Matrix Boston Consulting Group). In practice, most critics of matrix methods of economic analysis claim that they are not objective because of their two-dimensions and the positioning of the enterprise is performed only according to two indicators, the remaining indicators are not taken into account. That is why we support an alternative, according to some scientists (Biloshkurska, 2012) that it is possible to implement a three-dimensional model with the inclusion of the third evaluation criterion and the positioning of enterprises is performed not according to the matrix quadrant, but to the volumes of three-dimensional space. The axes of this three-dimensional model of strategic support of economic and institutional mechanism of economic security reflect the characteristics and indicators of the internal state of the enterprise, its relationship with the environment and the level of economic security.

\subsection{Enterprise as an object that provides strategic position to strengthen the economic security}

Considering the enterprise as an object of market relations we should focus on its position in the environment, not only as a supplier of production factors or products, but also as an object in the stock market, which will insure its strategic position of economic security strengthening.

Theory and practice of financial management (Brygchem, 1997); (Cheng, Johnson, \& Finnerty, 1990); (Modigliani \& Miller, 1963) has formed the principle of efficiency of business for the owner, which is to maximize the market value of the enterprise: the growth of the market value of the enterprise is the aim of the owner and the key element for economic security. Here you can see a direct link - increasing the rate of economic security triggers an increase in the market value of the enterprise and vice versa.

Comprehensive understanding of efficient management and development of the enterprise is formed by its market value, which is why the orientation of the enterprise to increase the market value creates the preconditions to 
strengthen its competitive position, enhances the viability and sustainability of the domestic and foreign markets. The market value of the enterprise is also a major criterion for investment decisions either for owner or external investor. Considering that the management process is impossible without reverse effect made by management object to its subject, while the principle of feedback indicates the fact of transmission of information from object to subject, thus the perception and processing of information is the basis for functioning of the management subject.

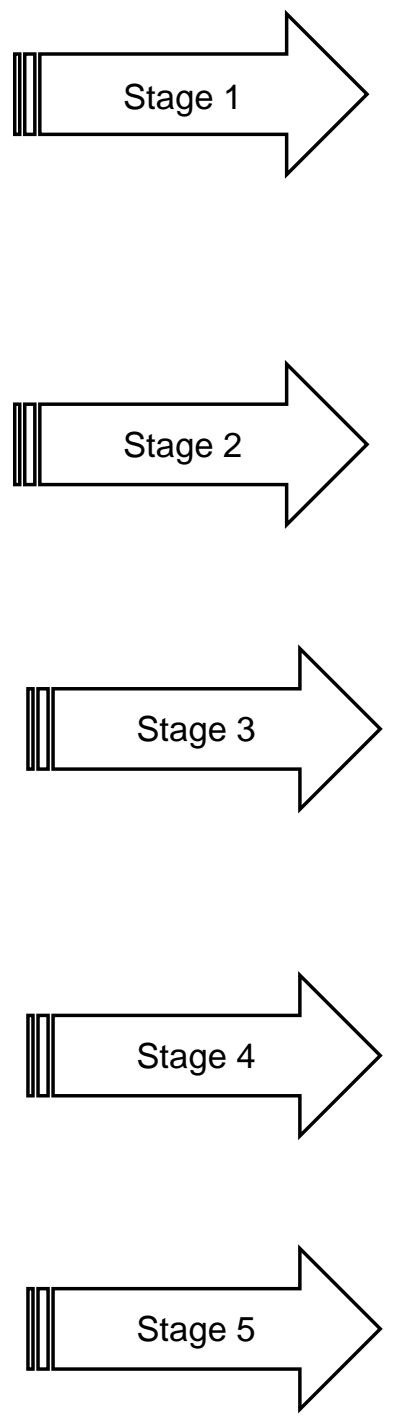

Defining the problem, "bottlenecks" and "risk zones"
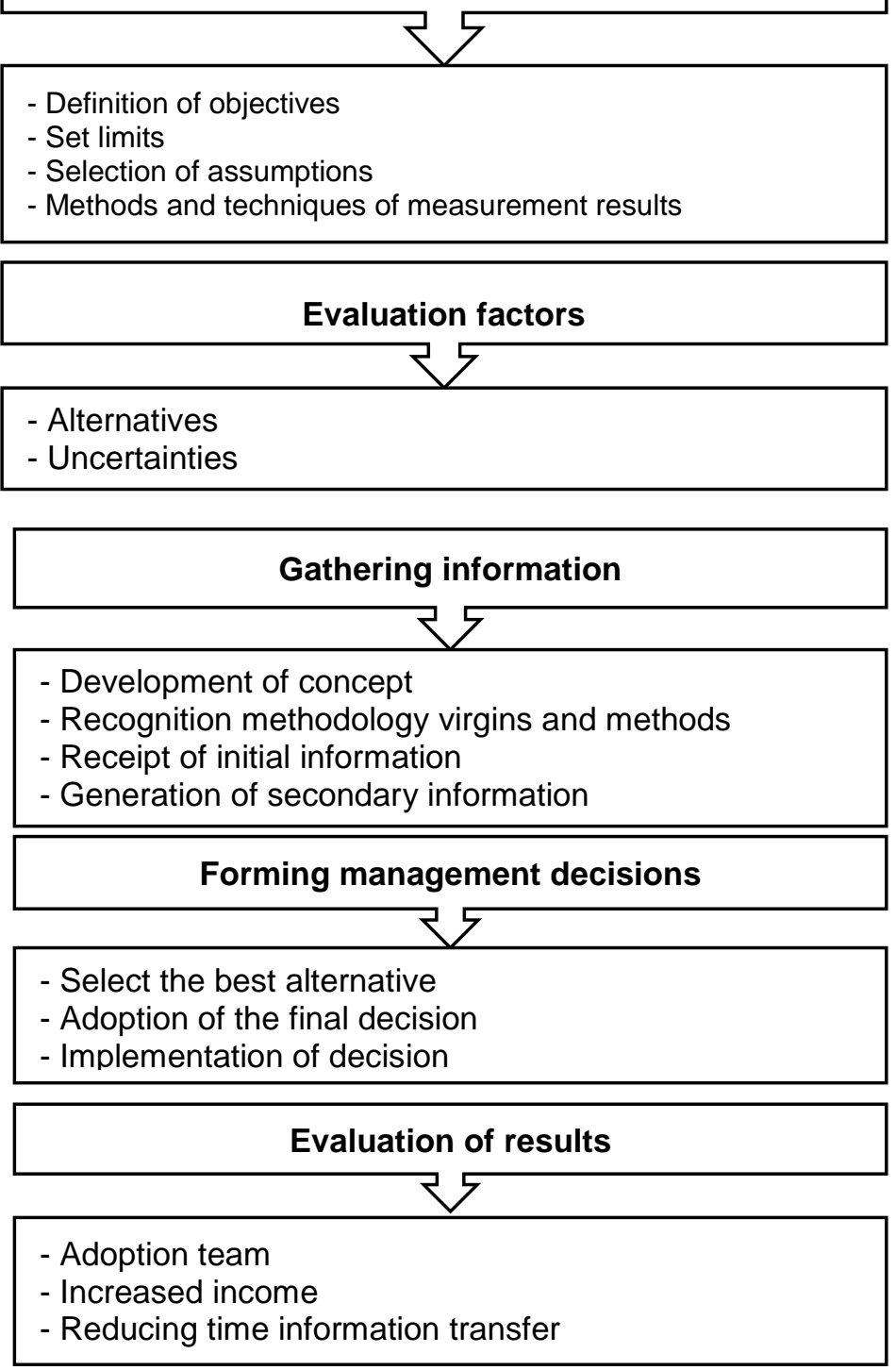

Fig. 2 Scheme of the formation of information management process of the enterprise

(Lichonosova, 2012)

For decision-making and management of the enterprise security particular attention is paid to the information provision of the enterprise. In our view, schematic phases of self-organization of the enterprise are quite aptly given by the author (Lichonosova, 2012) (Fig. 2.), which will be the basis of the information management process of the enterprise. 


\subsubsection{Stage 1}

At the first stage the formation of information provision is defined by "bottlenecks", "risk zones" of the enterprise; main groups of factors are: 1) the purpose - future revenues, market share, received by the enterprise due to its selforganization, 2) restrictions - factors that complicate achieving the purpose (money, time limits, "tunnel vision" of development directions), 3) presupposition - assumptions regarding factors and situations that make it easy to solve problems within the existing restrictions (expansion of enterprise's leaders values, extension of existing credit obligations), 4 ) ways of measuring the results - development of criteria and standards that would allow to conduct evaluation of the proposed actions aimed at enhancing self-organization. It is also necessary to define - why this or that information is important for the enterprise, is the qualification of the leaders and employees sufficient for its perception, processing, analyzing and use.

\subsubsection{Stage 2}

The second stage should conduct evaluation of factors, namely: alternatives - predictable and controllable factors and uncertainties - not controlled by the enterprise factors. The course of the process, the need of preparatory work and the expected volume should also be determined.

\subsubsection{Stage 3}

The third stage of information provision formation suggests finding a possible decision for selforganization. That is choosing the best available alternative, making the final decision and implementing it in the production and / or into management process. This step should also determine who controls the organizational work at the enterprise what are the levers for leveling the situation at the enterprise.

\subsubsection{Stage 4}

The fourth stage is the evaluation of the results of organizational activity which allows verifying the correctness of the decision of the organization, or vice versa - indicates its falsity. The resulting information at this stage must answer the question, what are the results of self-organization process. Is the further self-organization necessary and what its guidelines are.

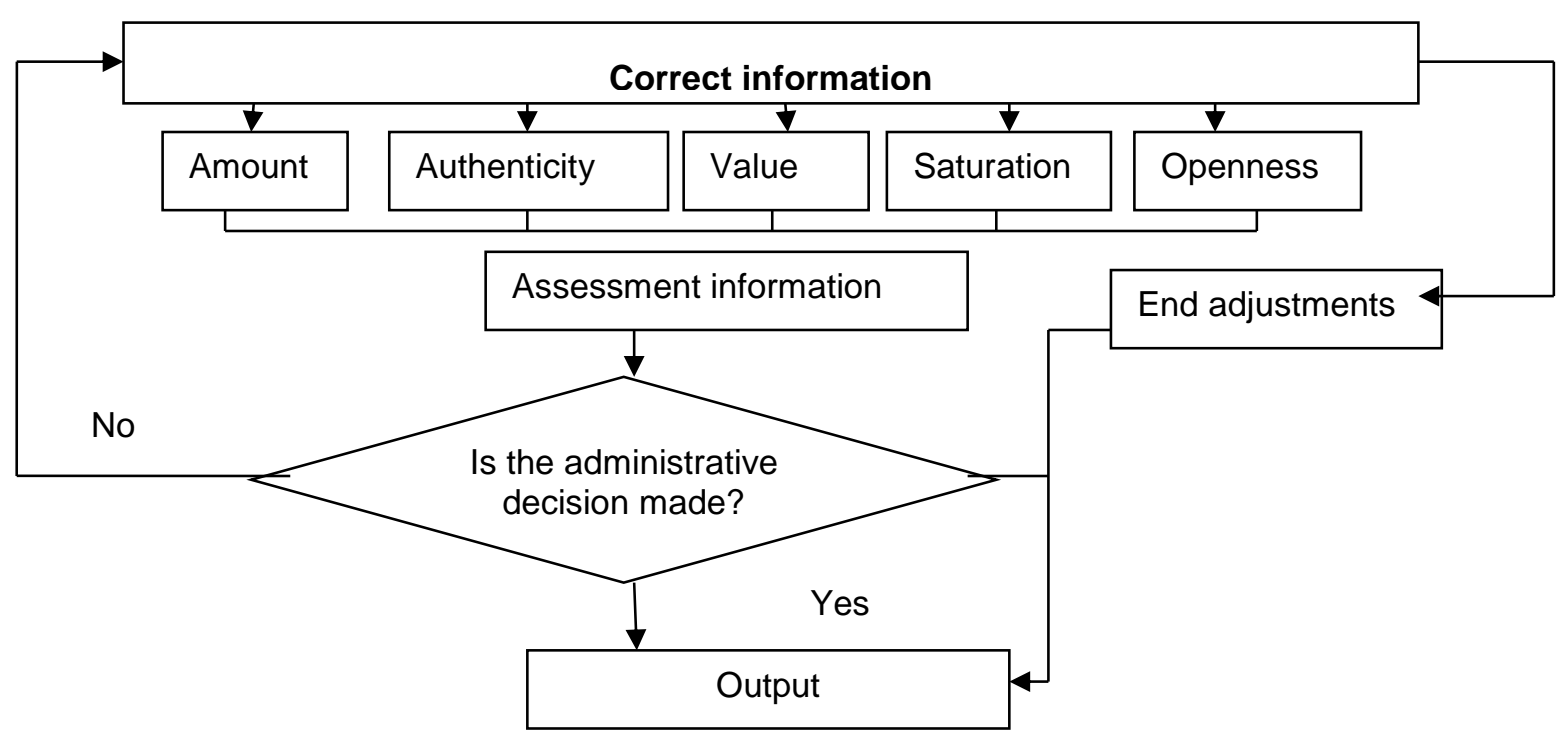

Fig.3. Algorithm of information correction according to the organization of management process

\subsection{Levels of information and its correction algorithm}

Based on the need to harmonize the organizational principles of management, formed information provision of the enterprise requires constant adjustment. Correction of information provision is necessary for certain filtering or to give it some emotional coloring. Determining the points of impact on information provision is 
necessary for effective correction. It is more effective to influence the information itself and the inherent characteristics in particular (Vasilenko, 2002) such as: volume, reliability, value, saturation and openness.

The amount of received information may have at least three levels: information redundancy, minimum required level, lack of information (information hunger).

Information redundancy concerning selforganization improves the quality of the decisions, however, increases the time for its processing and increases the value of information.

Lack of information makes it difficult to make the right decision, increases the risk and uncertainty of the situation requires advanced mathematical and economic methods to increase its probability for which experts and analysts are responsible, which also makes the cost of the decisions more expensive. The minimum required level of information - a minimum full information for managing subject in which he is able to make reasonable management decisions. It is clear that this level - is a subjective value and depends on the individual thesaurus of a certain person.

Correction of information provision according to this indicator should be aimed at manipulating the levels of received and transmitted amount of information (Fig. 3). For example, the head of the enterprise intentionally creates redundancy of information (if possible) or duplicates the information when making important decisions.

\subsection{Specifications of information}

\subsubsection{Reliability of information}

Reliability of information lies in the share of real information in total received data. Reliability also has three levels: absolute $(100 \%)$, confidential $(80 \%)$, negative (less than $80 \%)$. The fewer people are involved in collecting, processing and transmission of information, the higher is its probability. It largely depends on the time of information transmission. Even absolutely reliable information which was received by the recipient too late can be misleading (e.g., exchange rates or shares rates).

\subsubsection{Value of information}

The value of information is characterized by the reduction of the cost of resources (material resources, time and money) for making management decisions. It has four levels: zero, medium (reducing costs or increasing profits by more than 10\%), high (reducing costs by more than 2 times), and ultra-high (reducing costs by more than 10 times).

\subsubsection{Saturation of information}

Saturation of information - is the ratio of useful information and the background information. Background information is used for better perception of useful (professional) information by improving the mood, raising the emotional level of the recipient, by preceding focus on the topic. Such information may include: witty jokes, examples of situations of professional achievements, i.e. some deviation from the main topic - supporting and introductory information.

\subsubsection{Openness of information}

Openness of information - is an opportunity to present the information to different levels of employees and society in general. Examined characteristics of information are closely related to each other and affect each other, so the impact (correction) of one of the characteristics entails a change in others.

For example, increasing of the probability of information makes it necessary to increase its volume and openness.

\subsubsection{Place information provision and information security in business}

Thus, the final, corrected information used by the head of the enterprise for support or ending of the organizational process, should have the characteristics of information at this level:

- Volume: minimum required level;

- Value: the average and high level;

- Probability: absolute level;

- Saturation: average;

- Openness: confidential and public level. 


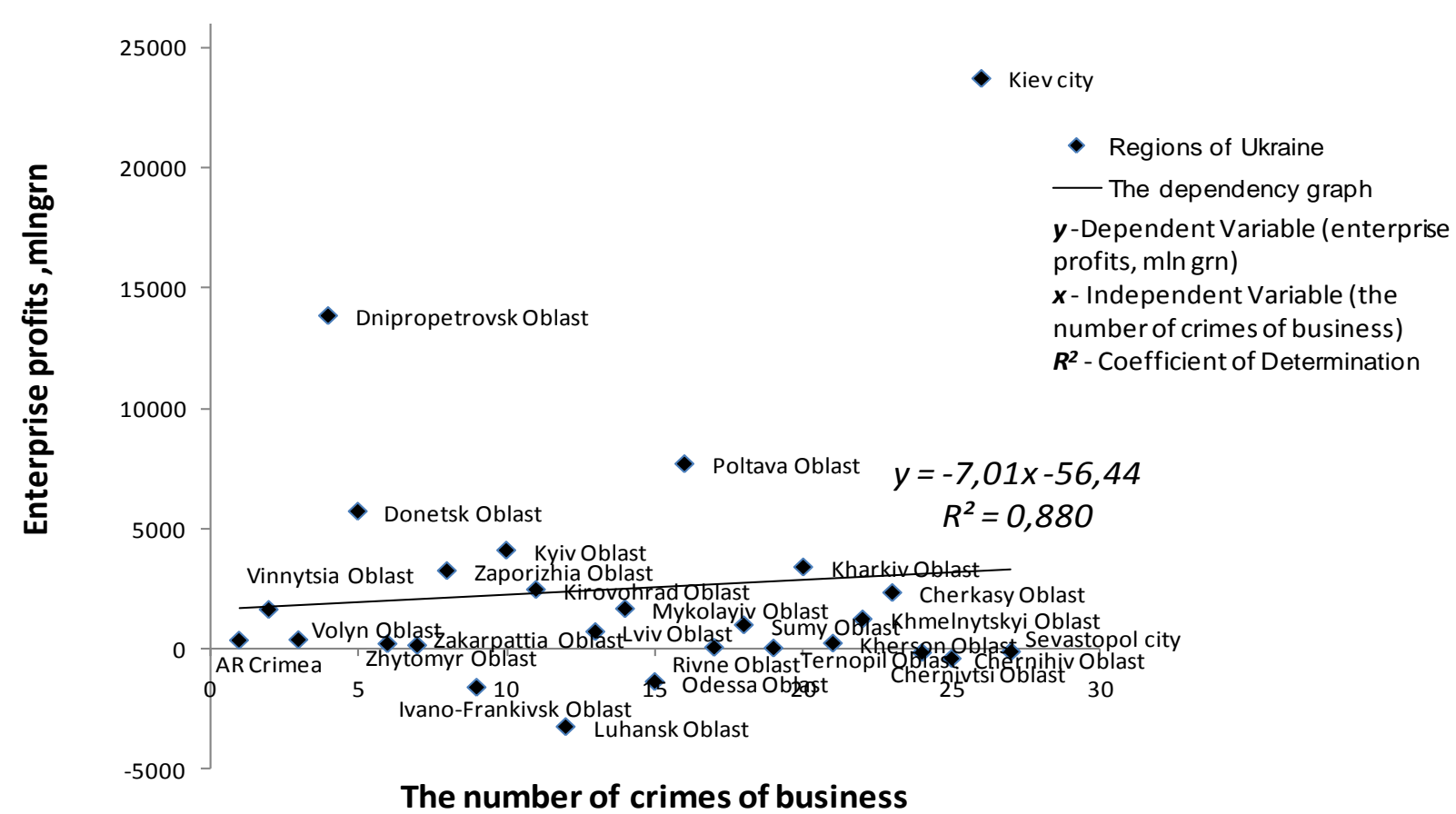

Fig.4. Dependence of profits of enterprises in Ukraine on the number of crimes in economic activity.

Calculated according to: (Ukrstat, 2013) (MIAU, p. 2012).

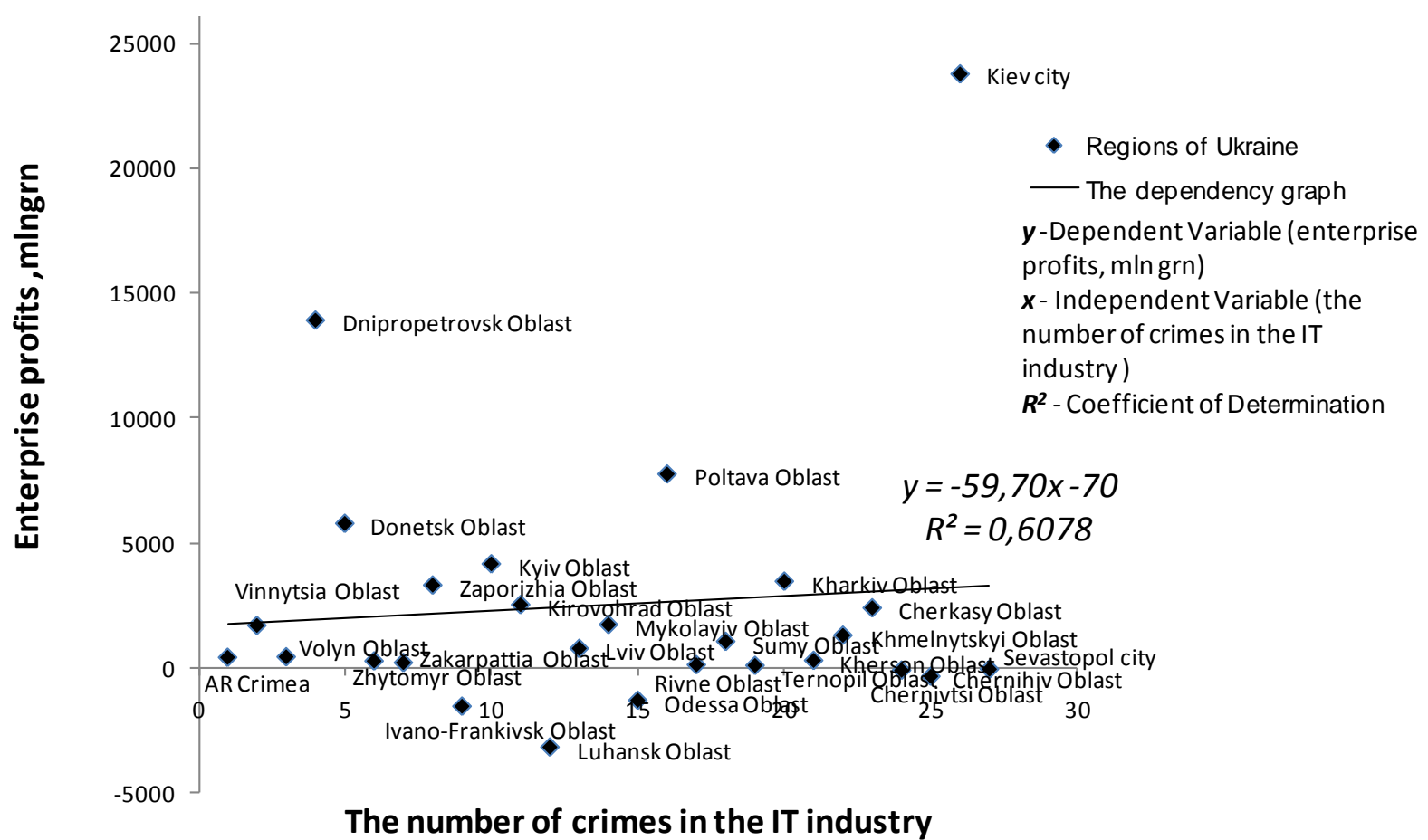

Fig.5. Dependence of profits of enterprises in Ukraine on the number of crimes in the sphere of information technologies

${ }^{*}$ Calculated according to: to (Ukrstat, 2013) (MIAU, 2012). 
Leaders of the enterprise come to understanding that information management and information security is more strategically important for business than IT.

Manifestations of economic crime have a direct impact on the financial results of the enterprises. Thus, according to our estimation, this dependence in Ukraine is described by the following parameters (Figure 4.): $Y=-7.01 \mathrm{x}$ 56.44 .

There is no doubt, that economic crimes are the key factor of economic security of enterprises.

Negative impact is also characteristic for spreading of criminal encroachments in the information technology at the enterprises.

Thus, crimes in the use of computers, (computer) systems, computer networks and telecommunications cause a decrease in profits in business for at least by $59.7 \%$ (Fig. 5).

Domestic enterprises equally suffer from abuses committed by both its employees and external fraud, while in 2009 the number of serious economic crimes committed by employees, increased by $22 \%$.

Most white collar swindlers in Ukraine are representatives of higher (40\%) and secondary (40\%) managerial levels (MIAU, p. 2012).

In regional aspect the largest number of crimes in economic activity is observed in Donetsk region. 1005 (in 2011). The second place according to this parameter occupies Dnipropetrovs'k region. 666 crimes. The same two regions are also leading in terms of the crimes committed in the use of computers (computer) systems, computer networks and telecommunications.

This fact confirms the crucial importance of information security for businesses, the necessity to develop effective measures to strengthen and counter threats and risks.

\section{CONCLUSIONS}

Thus, the information management process of the enterprise consists of: all the information necessary to manage all types of enterprise resources maintained in informational databases, development of informational environment for enhancing positive organizational activities of employees, providing them with the necessary information, and joining national or industrial search systems, receiving, storage, transmission and processing of information, i.e. the organization of appropriate databases. Based on the above, information provision of management process of the enterprise should include (Vasilenko, 2002; Zhyvko, Economico-pravovi aspekty upravlinnja ta zachystu intelektualnoi vlasnosty $\mathrm{v}$ umowach integracii ta bezpeky biznesu, 2011; Zhyvko, Systematic approach to the functioning of information management systems and quality control , 2010):

1. Providing management or other interested group of the enterprise with reliable, public information about the enterprise, aimed at organizational process and effective management. Effective method to provide such information may be available and constantly updated official business website on the Internet, conducting analytical work, participating in conferences and workshops.

2. Checking and public disclosure of the appropriate diligence of the enterprise as to its creditors and other liabilities. Such an examination includes: checking the financial and other information presented; accuracy of all records, including their compliance with applicable laws; qualification of leaders and employees of the enterprise or other initiators of the organizational process as individuals capable of meeting existing needs by ensuring the achievement of purposes on the basis of questionnaires. Such information should be within reach.

3. Using a wide range of information tools and practices for forecasting the enterprise activity. It is necessary to create a structure of competitive (business) intelligence, to develop a network of collection and analysis of data on future functioning of the enterprise - its macro environment of existence, internal psychological state of employees, financial parameters, and other. Developing on the basis of this information a model of the enterprise and this will widely characterize the enterprise at different stages of activity for making managing decisions. 
4. Using the information and psychological tools and methods for enhancing positive self-esteem of employees. Such means and methods of psychology evaluate thinking, management skills, factor of strong-will of the organization initiators to identify their motivation, levers of impact on their behavior or vice versa - to identify obsessive, manipulative behavior. They will enable a comprehensive understanding of the internal climate of the staff.

5. Creating the appropriate conditions for the development of organizational culture. Conducting series of organizational measures which would unite the staff, create friendly relations, would give a feeling of care from the side of management of the enterprise.

6. Providing the material and moral leverage to motivate staff to guarantee security of the enterprise.

7. Bringing up a sense of loyalty and commitment to the enterprise among the staff.

8. Considering the commercial information as a commodity, this can be costly for the enterprise and which requires constant security and is the basis for management decisions.

Biloshkurska. (2012). Vdoskonalennja ekonomiko-organizacijnogo mechanizmu ekonomicznoi bezpeky pidpryemstv APK. Efektyvna ekonomyka \#11, p. elektronnij resurs.

Brygchem, H. (1997). Finansovij menedzment t.2. S-Peterburg: Economiczeskaja shkola.

Cheng, L. F., Johnson, D. J., \& Finnerty, J. E. (1990). Corporate Finance: Theory, Method and Applications. San Diego: Harcourt Brace Jovanovich Publishers.

Czuzhikov, V. (2008). Modernizacia regionalnoi polytiky v ES. Ekonomika Ukraini \#4, pp. 56-63.

Lichonosova, G. S. (2012). Informacijne zabezpechennja samoorganizacii pidpriemstv. Efektyvna economika, p. online.

MIAU. (2012, 01 06). Stan ta struktura zlochinnosti v Ukraini. Retrieved 12 05, 2012, from Ministri of Intemal Affairs of Ukraine:

http://mvs.gov.ua/mvs/control/main/uk/publish/article/717134;jsessionid=9306BB7B0 3F86D5F234D8D9C0B75D472

Modigliani, F., \& Miller, M. H. (1963, 06). Taxes and the Cost of Capital: A Correction. American Economic Review, 433-443.

Sheil, M. S. (2008). Polityka spojnosci i polityka regionalna UE w nowym okresie programowania. (Komisja Europejska, Dyrekcja Generalna ds. Polytki Regionalnej) Retrieved 03 01, 2013, from Dom Europejski w Opolu: http://www.domeuropejski.pl/index.php?option=com_frontpage\&ltemid=169

Ukrstat. (2013). Net income with the distribution, medium and small companies in regions 2010-2012. Retrieved 02 05, 2013, from State Statistics Service of Ukraine: http://www.ukrstat.gov.ua

Vasilenko, V. A. (2002). Teoria i praktyka rozrobki upravlinskich ryshen. Kiev: TSUL.

Zhyvko Z.B. Ekonomico-pravovi aspekty uprawlinnja ta zachystu intelektualnoi vlasnosty $v$ umowach integracii ta bezpeky biznesu // Naukowi zapyski universytetu biznesu ta prava. Wypusk 6. 2011. - S.136-139.

Zhyvko Z.B. Systematic approach to the functioning of information management systems and quality control // Problems science. Interdisciplinary scientific and practical magazine. - Kyiv: CSTEI, 2010. - P. 24 - 32. 


\section{How to cite this article?}

Style - APA Sixth Edition:

Zhyvko, Z. (2013, 07 15). Economic security management of enterprises in the sphere of criminal challenges. (Z. Čekerevac, Ed.) MEST Journal, 1(2), 96-105. doi:10.12709/mest.01.01.02.09

Style - Chicago Fifteenth Edition:

Zhyvko, Zinaida. "Economic security management of enterprises in the sphere of criminal challenges." Edited by Zoran Čekerevac. MEST Journal (MESTE) 1, no. 2 (07 2013): 96-105.

Style - GOST Name Sort:

Zhyvko Zinaida Economic security management of enterprises in the sphere of criminal challenges [Journal] = Economic security management and criminal challenges // MEST Journal / ed. Čekerevac Zoran. - Belgrade : MESTE, 07 15, 2013. - 2 : Vol. 1. - pp. 96-105. - ISSN 2334-7058 (Online); ISSN 2334-7171.

Style - Harvard Anglia:

Zhyvko, Z., 2013. Economic security management of enterprises in the sphere of criminal challenges. MEST Journal, 15 07, 1(2), pp. 96-105.

Style - ISO 690 Numerical Reference:

Economic security management of enterprises in the sphere of criminal challenges. Zhyvko, Zinaida. [ed.] Zoran Čekerevac. 2, Belgrade : MESTE, 07 15, 2013, MEST Journal, Vol. 1, pp. 96-105. ISSN 2334-7058 (Online); ISSN 2334-7171. 